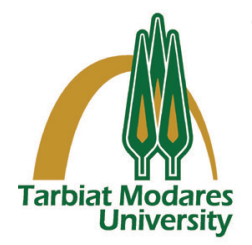

\title{
Molecular Detection of Cellulase -Encoding Gene in Thermophilic Streptomyces and Its Cloning in Escherichia coli Origami strain
}

\section{A R T I C L E I N F O}

Article Type

Original Research

Authors

Sara Seraj $M S c^{1}$

Sarvenaz Falsafi, $P h D^{1}$

Kumarss Amini, $P h D^{2}$

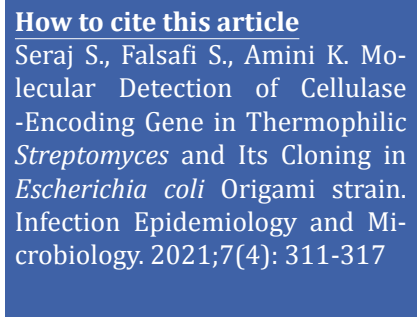

${ }^{1}$ Department of microbiology, faculty of advanced science and technology, Tehran branch, Tehran medical sciences, Islamic Azad University, Tehran, Iran.

${ }^{2}$ Department of Microbiology, School of Basic Sciences, Saveh Branch, Islamic Azad University, Saveh, Iran.

\footnotetext{
* Correspondence

Address: Department of microbiology, faculty of advanced science and technology, Tehran branch, Tehran medical sciences, Islamic Azad University, Tehran, Iran. sarvenaz_falsafi@yahoo.com
}

\begin{abstract}
A B S T R A C T
Background: Streptomyces is an aerobic filamentous Gram-positive bacterium frequently found in various environments worldwide. Cellulases are a group of glycosyl hydrolase enzymes that are frequently produced by bacteria. Thus, the aim of this study was to detect cellulase-encoding gene (celA) in soil-living Streptomyces strains and evaluate its cloning in Escherichia coli Origami strain.

Materials \& Methods: Soil samples were collected from a depth of 5-10 cm in Tehran, Iran. After identification of Streptomyces isolates by morphological and biochemical tests, genomic DNA was extracted. Polymerase chain reaction (PCR) test was employed to identify Streptomyces strains harboring the cellulase gene. The celA gene was positively transmitted to the host bacterium $E$. coli via a vector and cloned through the TA technique. Real-time PCR was used to measure the overexpression of this gene. ClustalX and Mega5 software were used to draw the phylogenetic tree.

Findings: Out of 12 Streptomyces isolates, 25\% were found to carry the celA gene. After cloning the celA gene, the cloned strains were chosen by colony selection (blue/white). The real-time PCR test showed the expression of the celA gene in the transformed strains. Phylogenetic analysis results using the neighbor-joining assay showed that Streptomyces spp. with $81 \%$ bootstrap were located in the same clade, indicating their close relatedness. Conclusion: Soil is one of the high-potential sources of the production of secondary metabolites, which could be used as a valuable source of various biological products such as cellulase.
\end{abstract}

\section{Keywords: Streptomyces, Cellulase, Cloning, TA cloning.}

\section{CITATION LINKS}

[1] Lizundia E, Puglia D, Nguyen TD, Armentano I. Cellulose... [2] Iguchi M, Yamanaka S, Budhiono A. Bacterial... [3] Cannon RE, Anderson SM. Biogenesis... [4] Wilson DB. Cellulases and... [5] Ryu DD, Mandels M. Cellulases: Biosynthesis and... [6] Bhat M. Cellulases and related enzymes in... [7] Singh A, Kuhad RC, Ward OP. Industrial application of microbial cellulases. In: Kuhad RC and Singh A, eds. Lignocellulose biotechnology: Future prospects. India, New Delhi: I.K. International Publishing... [8] Jayasekara S, Ratnayake R. Microbial cellulases: An overview and... [9] Kieser T, Bibb MJ, Buttner MJ, Chater KF, Hopwood DA. Practical... [10] Bibb MJ. Regulation of secondary metabolism in... [11] Taechowisan T, Lu C, Shen Y, Lumyong S. Secondary metabolites from endophytic Streptomyces aureofaciens CMUAc130 and their antifungal... [12] Maleki H, Dehnad A, Hanifian S, Khani S. Isolation and molecular identification of Streptomyces spp. with antibacterial... [13] Hoenich NA. Cellulose for medical applications: Past, present, and... [14] Behrouzpour E, Amini K. Molecular isolation, cloning, and expressions of L-glutaminase encoded gene from the aquatic... [15] Livak KJ, Schmittgen TD. Analysis of relative gene expression data using... [16] Deng SP, Tabatabai MA. Cellulase activity of soils. Soil.. [17] Sukumaran RK, Singhania RR, Pandey A. Microbial cellulases... [18] Maleki H, Dehnad A, Hanifian S, Khani S. Isolation and molecular identification of Streptomyces spp. with antibacterial activity from northwest of Iran. BioImpacts. 2013;3(3):129... [19] Deepthi MK, Sudhakar MS, Devamma MN. Isolation and... [20] Thakkar A, Saraf M. Application of statistically based... [21] Amore A, Pepe O, Ventorino V, Birolo L, Giangrande C, Faraco V. Cloning and recombinant expression of a cellulase from the... [22] Burlacu A, Cornea CP, Israel-Roming F. Screening... [23] Vadala BS, Deshpande S, Apte-Deshpande A. Soluble... [24] Wang J, Xu S, Pang Y, Wang X, Chen K, Ouyang P. Highly... [25] Sioud S, Aigle B, Karray-Rebai I, Smaoui $\mathrm{S}$, Bejar S, Mellouli L. Integrative gene cloning...

\section{Article History}

Received: September 052021

Accepted: October 25,2021

Published: November 05,2021

Copyright(C 2021, TMU Press. This open-access article is published under the terms of the Creative Commons Attribution-NonCommercial 4.0 International License which permits Share (copy and redistribute the material in any medium or format) and Adapt (remix, transform, and build upon the material) under the Attribution-NonCommercial terms. 


\section{Introduction}

Cellulose $\left(\mathrm{C}_{6} \mathrm{H}_{10} \mathrm{O}_{5}\right)_{n}$ as the most abundant carbon-based polymer is a polysaccharide consisting of an unbranched chain of $\beta$ $(1 \rightarrow 4)$-linked D-glucose units ${ }^{[1]}$. This organic polymer is an important structural constituent of the primary cell wall of green plants and many forms of algae and fungi ${ }^{[2]}$. Cellulase is a type of enzyme produced chiefly by various types of microorganisms. This enzyme catalyzes cellulolysis, which is the decomposition of cellulose and some associated polysaccharides ${ }^{[3]}$. Cellulases are a group of glycosyl hydrolase enzymes that hydrolyze cellulose $\beta$-1- and 4-glycosidic bonds; they are divided into three general categories: endoglucanases, exoglucanases, and glucosides ${ }^{[4]}$. Cellulase is used for commercial food processing in coffee ${ }^{[5]}$. Also, it is widely used in laundry detergents and in the textile industry ${ }^{[6]}$. They have also been used in the paper industry, fermentation of biomass into biofuels, and pharmaceutical applications [7]. Medically, this enzyme is used as a treatment for phytobezoars, a type of cellulose bezoar found in the human gastrointestinal tract. It has also been shown to be effective in degrading bacterial biofilms by disrupting $\beta$ (1-4) glycosidic linkages in the structural matrix of exopolysaccharides of extracellular polymeric substances [8].

Streptomyces is a Gram-positive filamentous bacterium that grows in many niche and has the ability to produce a numerous types of hydrolytic and industrially important extracellular enzymes such as cellulases ${ }^{[9]}$. These organisms are of great importance due to their unique ability to produce secondary metabolites and biologically active substances including preservatives, enzymes, and antibiotics [10]. Streptomyces spp. are of special importance due to the high species diversity (more than 500 species) and the production of $75-80 \%$ of all antibiotics ${ }^{[11]}$. Soli Streptomyces strains appear to be a potential source of bioactive compounds as well as a rich source of secondary metabolites ${ }^{[12]}$. They have a special place in the objectives of research programs due to their ability to produce new metabolites as well as important drug molecules. In 2006, Hoenich demonstrated the use of cellulase in medicine ${ }^{[13]}$. Cellulase was used as a hemodialysis tube in the treatment of renal failure and wound care. Objectives: The aim of this study was to detect cellulase-encoding gene in soil-living thermophilic Streptomyces strains and evaluate its cloning in E. coli Origami for used in wound dressing application.

\section{Materials and methods}

Sampling: In a period of eight months from April to November 2019, this cross-sectional study was performed in Tehran, Iran. In total, 60 soil samples were collected from a depths of 5 to $10 \mathrm{~cm}$ in pre-sterilized cellophane plastic bags and then sent to the laboratory. All samples were kept in the refrigerator until further used. During sampling, regionspecific characteristics such as $\mathrm{pH}$ value and altitude were documented.

Bacterial isolation: In general, $5 \mathrm{~g}$ of collected soil sample was transferred into a sterile bottle, then $45 \mathrm{~mL}$ of distilled water was added and shaken for $35 \mathrm{~min}$. Also, five sets of ten-fold serial dilutions were prepared from original supernatant, then $100 \mu \mathrm{L}$ of the third concentration was used for inoculation on starch casein agar (SCA) (Merck, Germany). The plates were incubated for 10 days at $28^{\circ} \mathrm{C}$. Morphological characteristics of colonies such as colony pigmentation were used for initial identification of the bacterial population. Dry and powdery colonies were isolated from the agar surface.

Molecular confirmation of Streptomyces species: Finally, all suspected grown Streptomyces colonies were confirmed using 16SrRNA specific primers amplification. 
Thus, template DNA was extracted from the isolates using a DNA extraction kit (Iranian Genetic Center Storage Kit). PCR was performed by 16srRNA primers (F5'AGAGTTTGATCCTGGCTCAG-3' and R:5'AAGGAGGTGATCCAGCCGCA-3') in a Eppendorf master thermal cycler (Eppendorf, Germany) with a final volume of $25 \mu \mathrm{L}$ per tube containing $0.09 \mu \mathrm{L}$ of templet DNA, $11.5 \mu \mathrm{L}$ of Taq DNA polymerase $2 x$ Master Mix Red, $1 \mu \mathrm{L}$ of each primer (10 pmol), and $10.6 \mu \mathrm{L}$ of $\mathrm{ddH}_{2} \mathrm{O}$. The reaction mixture was attained with the next PCR program as follows: an initial denaturation at $94{ }^{\circ} \mathrm{C}$ for $5 \mathrm{~min}$, followed by 32 cycles of denaturation at $94{ }^{\circ} \mathrm{C}$ for $60 \mathrm{~s}$, annealing at 53 ${ }^{\circ} \mathrm{C}$ for $30 \mathrm{~s}$, extension at $72{ }^{\circ} \mathrm{C}$ for $60 \mathrm{~s}$, and a final extension at $72{ }^{\circ} \mathrm{C}$ for $7 \mathrm{~min}$. PCR products were assessed using electrophoresis on 1.0\% agarose gel in TBE buffer at 100 volts for 120 $\mathrm{s}$, and DNA bands were imagined by DNA safe staining. The amplicon pattern was analyzed by NTSYS software (Version.2.0), and cluster analysis was performed to create dendrogram by unweighted pair group method with arithmetic averages (UPGMA) ${ }^{[12] .}$

\section{Detection of Cellulase-encoded} gene: The celA gene amplification test was performed by specific primers, including $F=$ 5'-AAGAGGACCTCGATATGATCTGGACACT-3' and $\mathrm{R}=5$ '-TCATCCCACATTCTAATGCCTGTAGGTA-3', in a master thermal cycler (Eppendorf, Germany) with $10 \mu \mathrm{L}$ of PCR Master Mix 2x (Amplicon), $1 \mu \mathrm{L}$ of each primers with a concentration of $10 \mathrm{pm} /$ $\mu \mathrm{L}, 1 \mu \mathrm{L}$ of template DNA (150 ng), and $12 \mu \mathrm{L}$ of $\mathrm{ddH}_{2} \mathrm{O}$. PCR conditions were as follows: an initial denaturation at $95^{\circ} \mathrm{C}$ for $7 \mathrm{~min}$, followed by 30 cycles of denaturation at $95^{\circ} \mathrm{C}$ for $30 \mathrm{~s}$, annealing at $56{ }^{\circ} \mathrm{C}$ for $30 \mathrm{~s}$, extension at $72{ }^{\circ} \mathrm{C}$ for $1 \mathrm{~min}$, and a final extension at $72{ }^{\circ} \mathrm{C}$ for $10 \mathrm{~min}$. PCR amplicons were observed by electrophoresis on $1.5 \%$ agarose gel in TBE buffer stained by DNA safe staining.

CelA gene cloning in $\boldsymbol{E}$. coli origami: The celA gene PCR products were extracted, purified using a gel extraction kit (Roche), and ligated to the pTZ57R (MBI fermentas) cloning vector. Ligation was performed using T4 DNA ligase (fermentas). The plasmids were transferred into the competent $E$. coli origami ${ }^{\mathrm{TM}}$ (DE3) according to the manufacturer's procedures. The mineral salt glutamine (Sigma Aldrich, Germany) comprising $100 \mu \mathrm{g} / \mu \mathrm{L}$ ampicillin was used to select colonies. White colonies were chosen, overnight cultivated, and subjected to plasmid extraction and PCR. In order to confirm the accuracy of the cloned fragments, the selected recombinant plasmids were sent for Sanger sequencing (MWG service) ${ }^{[14]}$. Cloned celA gene expression by real-time PCR Extraction of mRNA was performed in a late log phase by RNeasy Midi Kit (Qiagen), and complementary DNA (cDNA) was synthesis using a Smart PCR cDNA synthesis kit (Clontech, Palo Alto, CA, USA). The RNA concentration was quantified with a spectrophotometer at 260/280 nm. Reaction was done using a $2 \times$ GreenStar Master Mix Kit (Bioneer, Korea) on a Corbett Rotor-Gene 6000 real-time rotary (Corbett Life Science, Australia). The quantitative real-time PCR $(25 \mu \mathrm{L})$ reaction mixture contained 11.5 $\mu \mathrm{L}$ of PCR Master Mix, $1 \mu \mathrm{L}$ of cDNA, 0.7 $\mu \mathrm{L}$ of $0.8 \mu \mathrm{M}$ solutions of both forward and reverse gene-specific primers, and $11.1 \mu \mathrm{L}$ of double distilled water. The real time-PCR was done based on the following program: an initial denaturation at $95{ }^{\circ} \mathrm{C}$ for $60 \mathrm{~s}$, followed by 33 cycles of multiplication at 94 ${ }^{\circ} \mathrm{C}$ for $30 \mathrm{~s}, 57{ }^{\circ} \mathrm{C}$ for $40 \mathrm{~s}$, and $72{ }^{\circ} \mathrm{C}$ for 60 s. All experiments were run in triplicate. A critical threshold cycle (CT) value was used to present CelA transcripts quantitatively. The $\Delta \mathrm{CT}$ for celA transcripts was measured in comparison to the $\beta$-actin gene. The celA relative expression was assessed by the $2^{-\Delta \Delta}$ CT method [15].

\section{Findings}

Based on the morphological features and 
microscopic examination, such as whiteness, dryness, and gypsum-like appearance of colonies, odor due to physiological activities, and slide culture, $20 \%(n=12$ of 60 ) of the isolates were identifies as Streptomyces among the strains isolated from the soil samples (Figures 1A and 1B). All isolates were confirmed by $16 \mathrm{~s}$ rRNA amplification test.
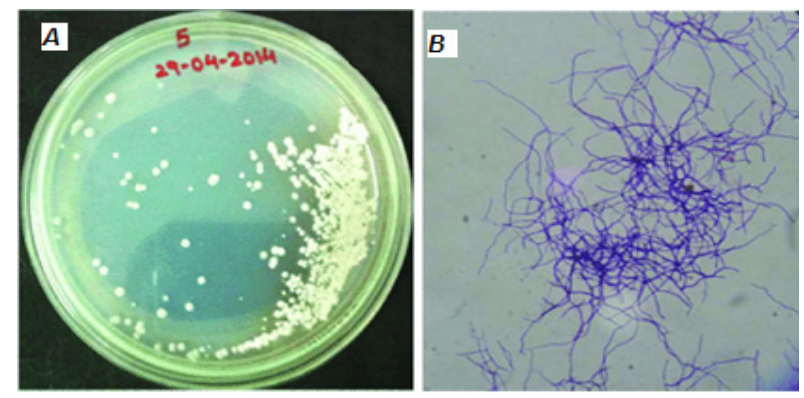

Figure 1) Morphologicaland microscopiccharacteristics of Streptomyces strains isolated in this study. 1A and 1B: white colonies and filamentous Gram-positive bacteria

The results of PCR reaction for the celA gene showed that out of 12 Streptomyces strains, $25 \%(n=3$ of 12$)$ were positive for the presence of this gene. All celA-positive strains were sequenced by Sanger method (Figures $2 \mathrm{~A}$ and $2 \mathrm{~B}$ ).

After TA cloning of the cellulase -encoding gene, the cloned strains were picked by colony selection (blue/white colonies). In order to confirm the results of cloning, transformed DNAs were extracted, and PCR

A

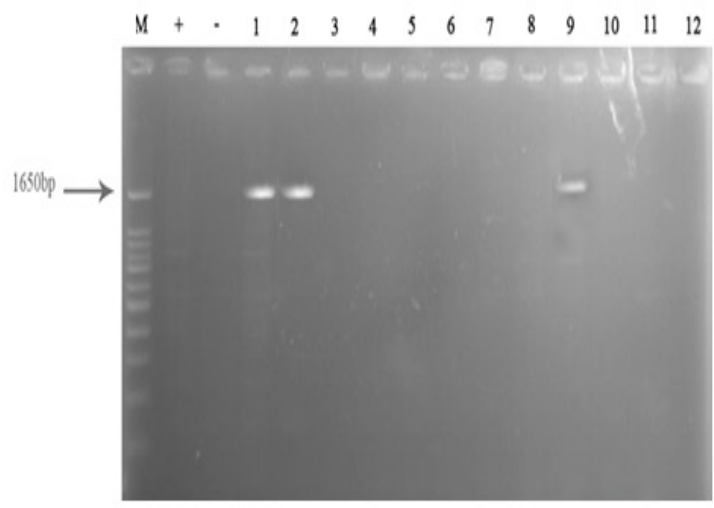

sequencing was performed. The presence of a $234 \mathrm{bp}$ fragment indicated a successful cloning. Lastly, the celA gene cloning in E. coli isolates was confirmed using PCR sequencing method (Figures $3 \mathrm{~A}, 3 \mathrm{~B}$, and $3 \mathrm{C}$ ). The quantitative real-time PCR test showed successful expression of the celA gene in cloned strains with $\mathrm{Tm}=86.94$ (Figure 4a). The results of phylogenetic relatedness using the neighbor joining (NJ) method showed that Streptomyces BPSEAC7 species with 81\% bootstrap and Streptomyces MI02-7b were located in the same cluster, indicating their close relationship with each other (Figure 4b).

\section{Discussion}

Enzymes are proteinaceous substances that act as catalysts and accelerate biological reactions [16]. Cellulases are important textile, industrial, and medical enzymes that have attracted much attention in recent decades due to their diverse applications ${ }^{[6]}$. This enzyme is not actually a single enzyme, but a complex multi-enzyme system produced and secreted by specific microorganisms such as bacteria, yeasts, and fungi ${ }^{[8]}$. Of all the enzyme-producing strains, including, Bacillus, Micrococcus, Pseudomonas, and Actinomycetes, only Streptomyces strains (a genus from Actinomycetes) are commercially available ${ }^{[17]}$.

Bioneer
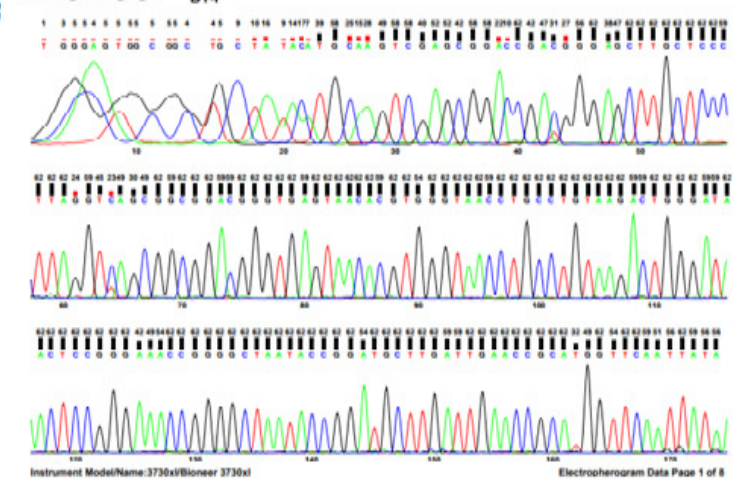

Figure 2) PCR results of celA genes: $2 \mathrm{~A}: \mathrm{C}+$ : positive control, $\mathrm{C}-:$ negative control (distilled water), and Wells 1 to 12 : Streptomyces strains, $2 \mathrm{~b}$ : the result of sequencing and BLAST of the amplified gene 

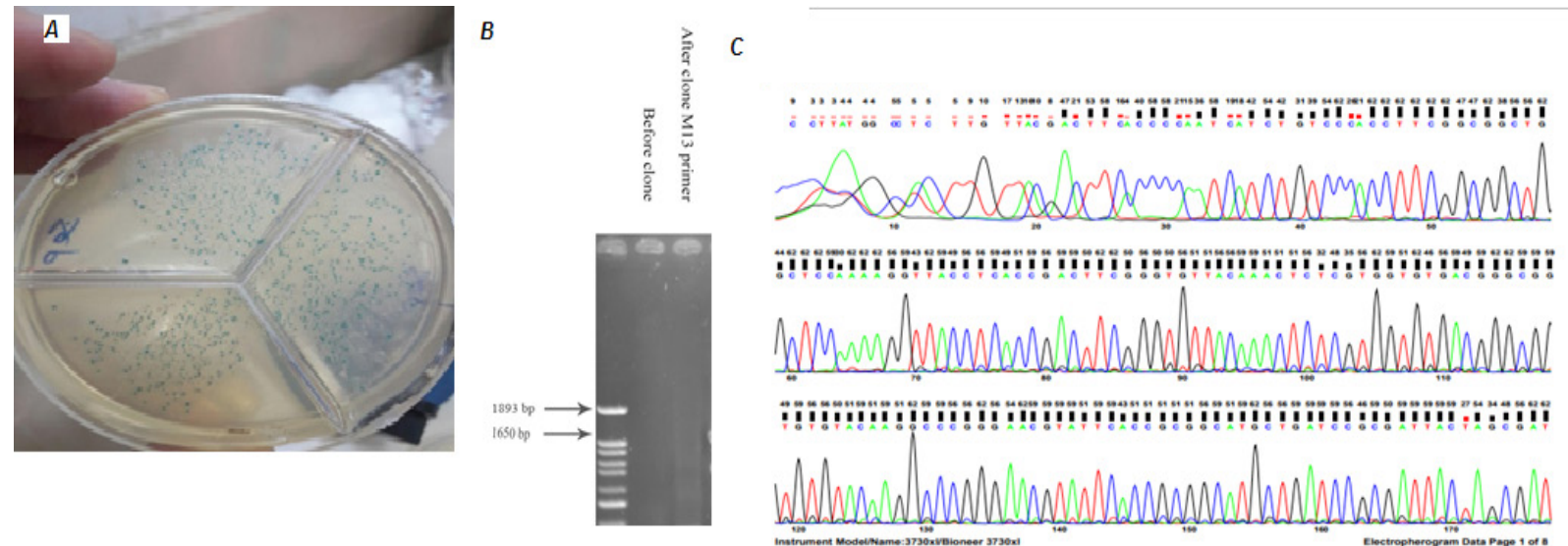

Figure 3) Results of A: clonal selection of celA gene (white and blue colonies), B: confirmation of cloning by PCR with M13 vector primers and its sequence, C: BLAST of PCR result
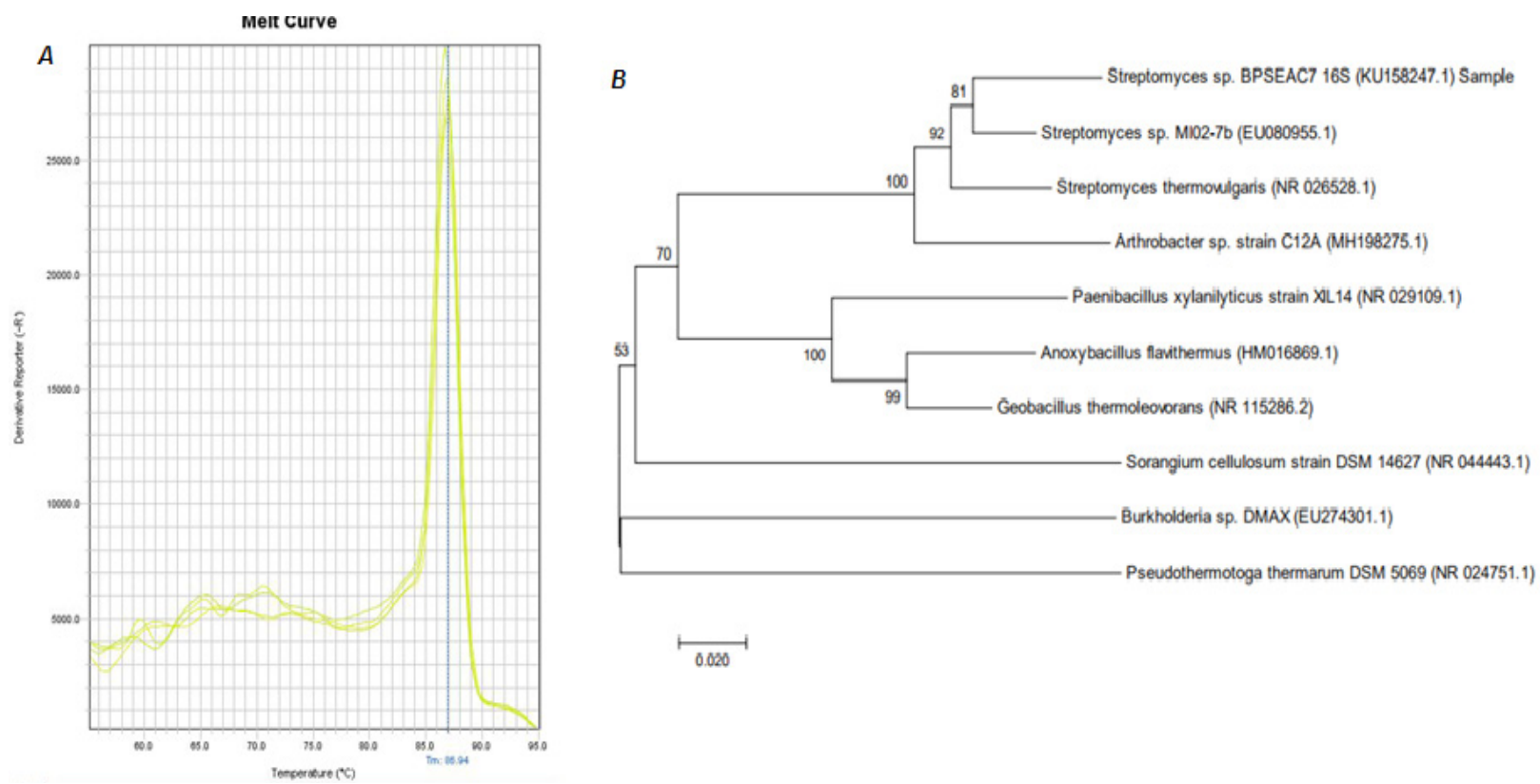

Figure 4) A: Real time PCR melting curve results, B: phylogenetic tree

Some previous studies have shown that the celA gene is found in soil Streptomyces; therefore, soil Streptomyces strains are a potential source for the production of this enzyme. In agreement with Behroozpour et al. (2019) ${ }^{[14]}$ and Maleki et al. (2013) [18], Streptomyces strains in this study were isolated from the soil samples. In concordance with the present study, Maleki et al. (2013) ${ }^{[18]}$ showed that soil of northwestern Iran could be used as a rich source to study novel Streptomyces strains with high potency of enzyme production. This could be due to the soil moisture content and $\mathrm{pH}$. In the current study, of 12 Streptomyces isolates collected, three isolates carried the celA gene. In line with this study, Deepthi et al. (2012) ${ }^{[19]}$ isolated the cellulase enzyme from soil Streptomyces isolates. Thakkar et al. (2014) ${ }^{[20]}$ and Amore et al. (2012) ${ }^{[21]}$ detected cellulaseencoding gene in soil-living Streptomyces isolates. The results of phylogenetic relatedness using the $\mathrm{NJ}$ method showed 
that Streptomyces BPSEAC7 species with 81\% bootstrap and Streptomyces MI02-7b were located in the same cluster, indicating their close relationship with each other. In agreement with the present study, Amore et al. (2012) [21] showed that the highest cellulolytic activity was identified by $16 \mathrm{~S}$ rRNA sequencing and belonged to the genus Streptomyces and designated as Streptomyces sp. strain G12. Contrary to the present study data, in a study directed by Thakkar et al. (2014) ${ }^{[20]}$, the purified PCR amplicon was sequenced, and the phylogenic relationship was determined by comparing the sequence data with the existing sequences available in the NCBI gene bank sequence database (Bethesda, MD, USA) and recognized as $B$. amyloliquefaciens denoted as MBAA3. Then the sequence was deposited in the gene bank under the accession number KF535140. This inconsistency could be due to geographical and ecological differences and the materials used in these study. Limitations of this work include soil type and cloning errors.

In a parallel study, Burlacu et al. (2016) showed that the best Xylanases activities were found in $B$. amyloliquefaciens, Aspergillus brasiliensis, Penicillium digitatum. and $A$. niger ${ }^{[22]}$. Vadala et al. (2021) showed that extracellular cellulase production by B. subtilis was confirmed firstly on the CMC agar, and then cellulase-encoding gene was detected by PCR test. This gene was then cloned into the pET21a expression vector. As a result, the researchers stated that soluble expression of active recombinant cellulase could be completed by subtle modification in the upstream procedure [23]. Wang et al. (2020) showed that the host strain E. coli BL21 (DE3) could express streptomycinderived extracellular recombinant phospholipase D with high efficiency ${ }^{[24]}$. The differences observed between the results of the above and present studies could be attributed to the type of sample, the source of cellulase separation (thermophilic Streptomyces vs, other resources), fermentation conditions, difference in the type of expression vector, and difference in the cloning methodology. Cloning conditions also affect the product expression in the expression vector.

Sioud et al. (2009) showed that the xylA gene (encoding for glucose isomerase) from Streptomyces sp. SK was successfully expressed in Streptomyces sp. TN 58. Data showed that heterologous glucose isomerase could be expressed and folded effectively. Glucose isomerase activity of the constructed TN 58 recombinant isolate was about 18fold higher than that of Streptomyces sp. SK ${ }^{[25]}$. These findings are certainly important due to the potential use of better strains in biotechnological methods to produce highfructose syrup from starch.

\section{Conclusion}

It could be concluded that soil-living Streptomyces strains are one of the highpotentialsourcesfortheproduction of secondary metabolites, which could be used to produce various biological products such as cellulase. Since cellulase has different applications, the search for organisms producing this enzyme is one of the main ways to achieve enzymes with ideal properties.

\section{Acknowledgements}

All authors thanks to the Pasargad research laboratory staffs for their collaboration in this work.

Ethical Permission: As the work is an industrial research we haven't received ethical permission yet.

Conflicts of interest: All authors declare that there are no conflicts of interest.

Authors Contribution: Conceptualization: SF, SS; Data curation: SF, SS; Formal analysis: SF, SS; Funding acquisition: SF, SS, KA; investigation: SF, SS; Methodology: SF, SS; Project administration: SF; Resources: SF, SS; Software: SF, SS; Supervision: SF; Writing of 
the original draft: SF, SS; Writing-review and editing: SF, SS.

Fundings: None.

Consent to participate: Not Applicable.

\section{References}

1. Lizundia E, Puglia D, Nguyen TD, Armentano I. Cellulose nanocrystal based multifunctional nanohybrids. Prog Mater Sci. 2020;112:100668.

2. Iguchi M, Yamanaka S, Budhiono A. Bacterial cellulose-a masterpiece of nature's arts. J Mater Sci. 2000;35(2):261-70.

3. Cannon RE, Anderson SM. Biogenesis of bacterial cellulose. Crit Rev Microbiol. 1991;17(6):435-47.

4. Wilson DB. Cellulases and biofuels. Curr Opin Biotechnol. 2009;20(3):295-9.

5. Ryu DD, Mandels M. Cellulases: Biosynthesis and applications. Enzyme Microb Technol. 1980;2(2):91-102.

6. Bhat M. Cellulases and related enzymes in biotechnology. Biotechnol Adv. 2000;18(5):355-83.

7. Singh A, Kuhad RC, Ward OP. Industrial application of microbial cellulases. In: Kuhad RC and Singh A, eds. Lignocellulose biotechnology: Future prospects. India, New Delhi: I.K. International Publishing House; 2007, 345-58.

8. Jayasekara S, Ratnayake R. Microbial cellulases: An overview and applications. In: Pascual AR and Eugenio Martin M, eds. Cellulose. Intechopen; 2019, 83-100.

9. Kieser T, Bibb MJ, Buttner MJ, Chater KF, Hopwood DA. Practical Streptomyces genetics. Norwich: John Innes Foundation; 2000.

10. Bibb MJ. Regulation of secondary metabolism in streptomycetes. Curr Opin Microbiol. 2005;8(2):208-15.

11. Taechowisan T, Lu C, Shen Y, Lumyong S. Secondary metabolites from endophytic Streptomyces aureofaciens CMUAc130 and their antifungal activity. Microbiology. 2005;151(5):1691-5.

12. Maleki H, Dehnad A, Hanifian S, Khani S. Isolation and molecular identification of Streptomyces spp. with antibacterial activity from northwest of Iran. BioImpacts. 2013;3(3):129-34.

13. Hoenich NA. Cellulose for medical applications: Past, present, and future. BioResources.
2006;1(2):270-80.

14. Behrouzpour E, Amini K. Molecular isolation, cloning, and expressions of L-glutaminase encoded gene from the aquatic Streptomyces collected from Persian Gulf. Int J Mol Clin Microbiol. 2019;9(2):1181-7.

15. Livak KJ, Schmittgen TD. Analysis of relative gene expression data using realtime quantitative PCR and the 2- $\Delta \Delta$ CT method. Methods. 2001;25(4):402-8.

16. Deng SP, Tabatabai MA. Cellulase activity of soils. Soil Biol Biochem. 1994;26(10):1347-54.

17. Sukumaran RK, Singhania RR, Pandey A. Microbial cellulases production, applications, and challenges. J Sci Ind Res. 2005;64(11):832-44.

18. Maleki H, Dehnad A, Hanifian S, Khani S. Isolation and molecular identification of Streptomyces spp. with antibacterial activity from northwest of Iran. BioImpacts. 2013;3(3):129.

19. Deepthi MK, Sudhakar MS, Devamma MN. Isolation and screening of Streptomyces sp. from Coringa mangrove soils for enzyme production and antimicrobial activity. Int J Pharm Chem Biol Sci. 2012;2(1):110-6.

20. Thakkar A, Saraf M. Application of statistically based experimental designs to optimize cellulase production and identification of gene. Nat Prod Bioprospect. 2014;4(6):341-51.

21. Amore A, Pepe O, Ventorino V, Birolo L, Giangrande C, Faraco V. Cloning and recombinant expression of a cellulase from the cellulolytic strain Streptomyces sp. G12 isolated from compost. Microb Cell Factories. 2012;11(1):164.

22. Burlacu A, Cornea CP, Israel-Roming F. Screening of xylanase producing microorganisms. Res J Agric Sci. 2016;48(2):8-15.

23. Vadala BS, Deshpande S, Apte-Deshpande A. Soluble expression of recombinant active cellulase in E. coli using B. subtilis (natto strain) cellulase gene. J Genet Eng Biotechnol. 2021;19(1):1-7.

24. Wang J, Xu S, Pang Y, Wang X, Chen K, Ouyang P. Highly efficient extracellular production of recombinant Streptomyces PMF phospholipase D in Escherichia coli. Catalysts. 2020;10(9):1057.

25. Sioud S, Aigle B, Karray-Rebai I, Smaoui S, Bejar $\mathrm{S}$, Mellouli L. Integrative gene cloning and expression system for Streptomyces sp. US 24 and 